\title{
Screening of a combinatorial library reveals peptide- based catalysts for phosphorester cleavage in water
}

Carsten Schmuck* and Jürgen Dudaczek

University of Würzburg, Institute of Organic Chemistry, Am Hubland, 97074 Würzburg, Germany

schmuck@chemie.uni-wuerzburg.de

\section{Supporting Information}

NMR spectra, ESI-MS and IR-spectra of peptide 1c (2-7)

Selected peptide sequences from the library screening and their activity (8) 


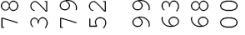
$\dot{\theta} \dot{ }$

Na $\infty$ - $m$ m

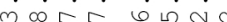

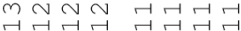

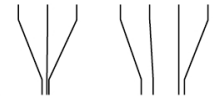

में

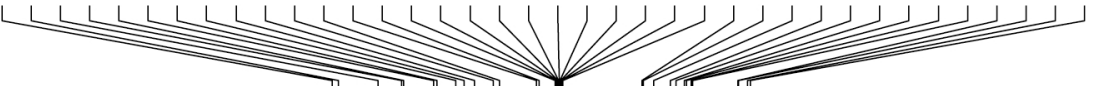

1c = Cbz-His-Gly-Gua-D-Pro-Aib-Gua-Gly-Val-NH-R

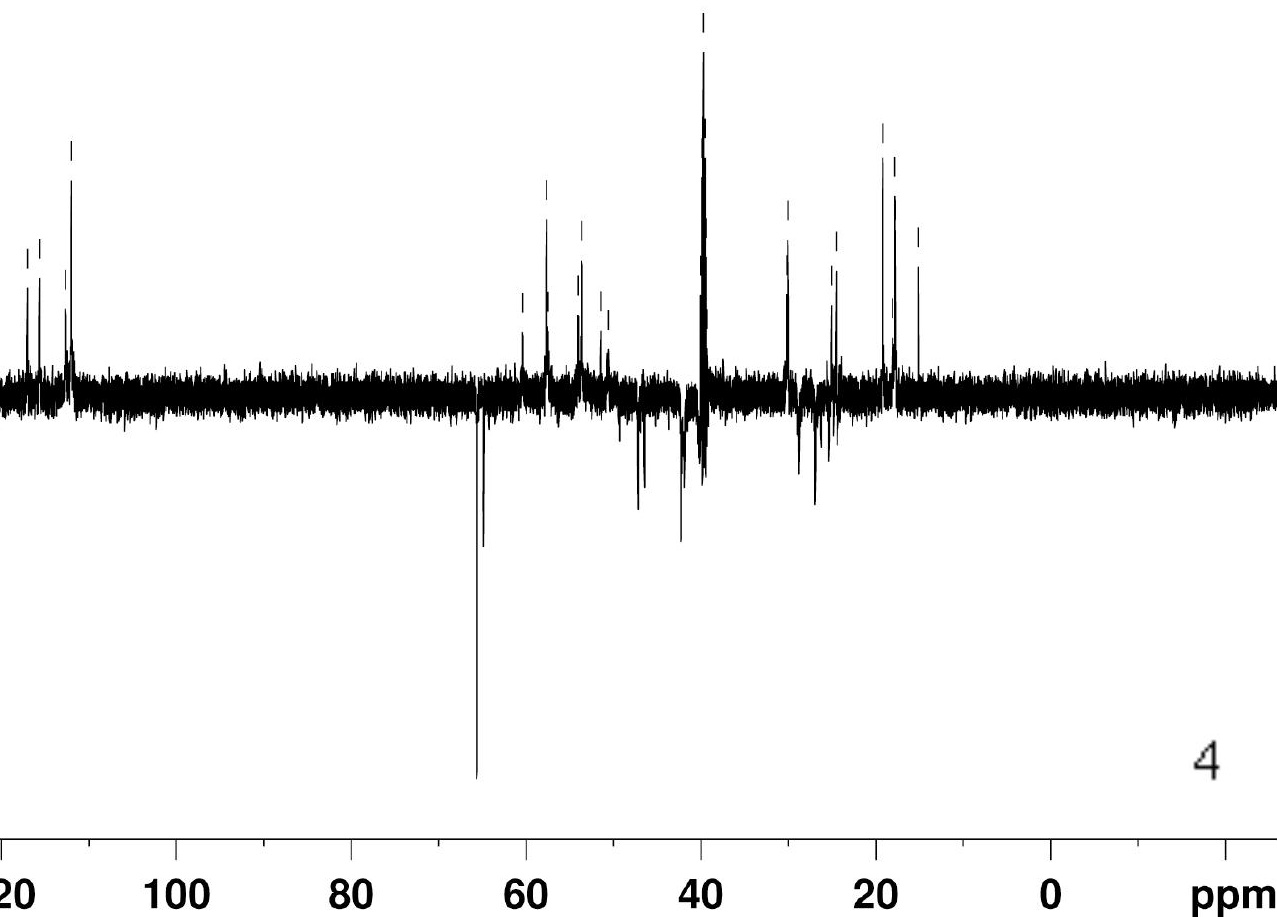




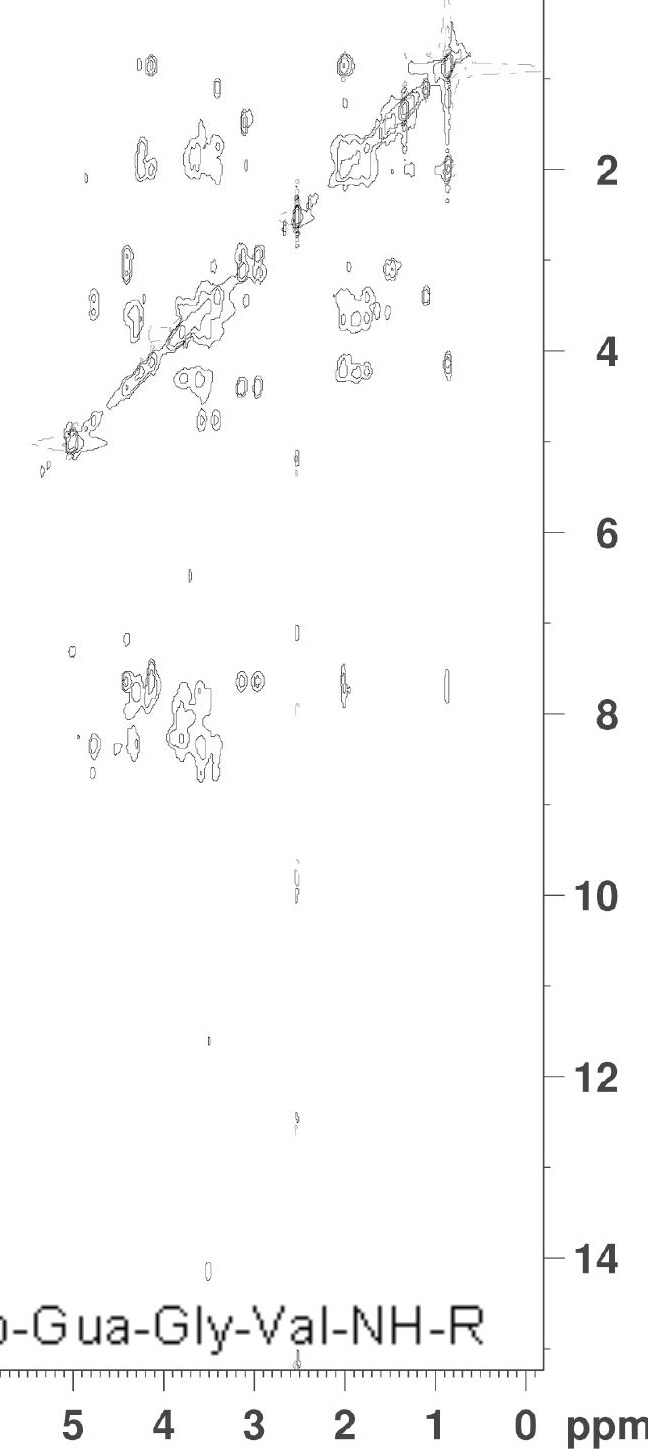




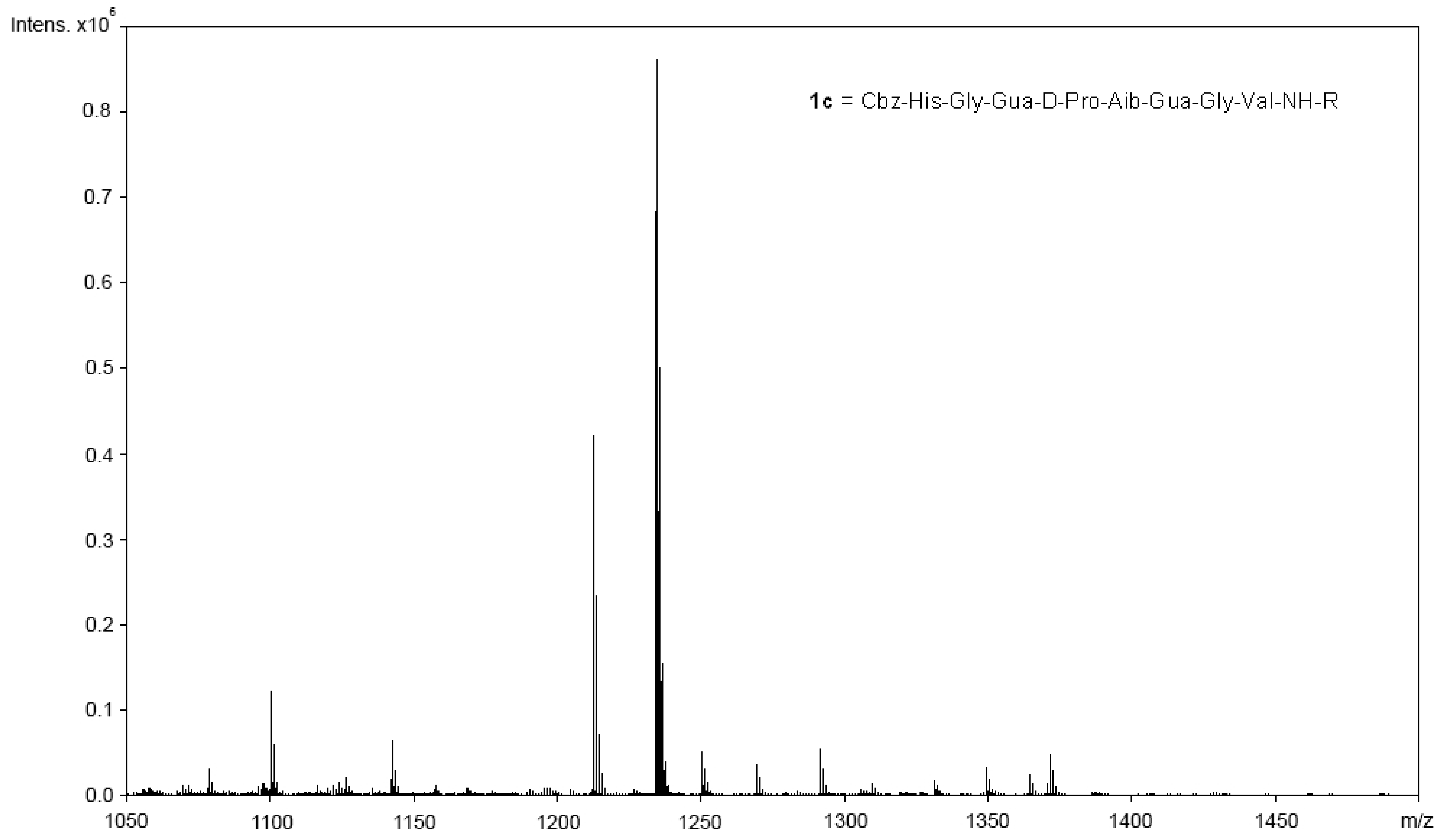




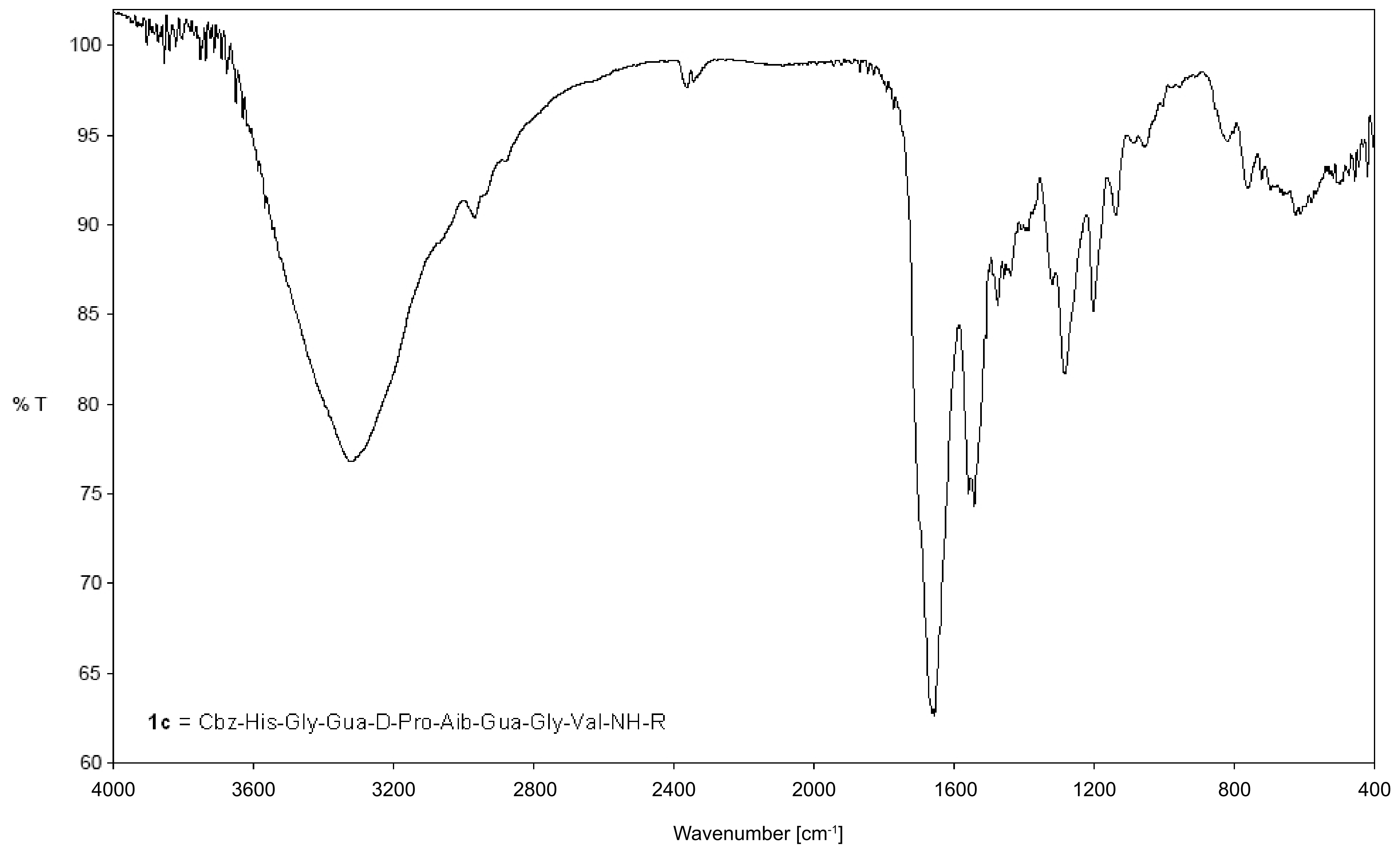


selected sequences from the library screening in addition to the most active one, $\mathbf{1 c}$

P1-H5:

$\mathrm{NH}_{2}$-Val-Gly-Asp-Aib-Pro-Ser-Gly-Ser-NHCbz weak

P1-G2:

$\mathrm{NH}_{2}$-Glu-Gly-His-Aib-Pro-Glu-Gly-Ser-NHCbz weak

$\mathrm{P} 2-\mathrm{H} 12$ :

$\mathrm{NH}_{2}$-His-Gly-Asp-Aib-Pro- $\mathrm{C}_{1}$-Gly-Ser-NHCbz

medium

P2-A12:

$\mathrm{NH}_{2}$ - $\mathrm{C}_{1}$-Gly-Asp-Aib-Pro- $\mathrm{C}_{1}$-Gly-His-NHCbz

weak

P3-F1:

$\mathrm{NH}_{2}$ - $\mathrm{C}_{1}$-Gly-Asp-Aib-Pro-Glu-Gly-Ser-NHCbz

medium

P4-H8:

$\mathrm{NH}_{2}$ - $\mathrm{C}_{1}$-Gly-Ser-Aib-Pro-Phe-Gly-Val-NHCbz

medium

P5-B2:

$\mathrm{NH}_{2}-\mathrm{C}_{1}$-Gly-Ser-Aib-Pro-Phe-Gly-Ser-NHCbz medium-strong

P5-G7:

$\mathrm{NH}_{2}$-Ser-Gly-C $\mathrm{C}_{1}$-Aib-Pro-Phe-Gly-Ser-NHCbz weak-medium

P6-C12:

$\mathrm{NH}_{2}$-Val-Gly-Phe-Aib-Pro- $\mathrm{C}_{1}$-Gly-Val-NHCbz

weak-medium

P6-H1:

$\mathrm{NH}_{2}$-Ser-Gly- ${ }_{1}$-Aib-Pro- $\mathrm{C}_{1}$-Gly-Val-NHCbz

medium

P7-D10:

$\mathrm{NH}_{2}$-Ser-Gly-Asp-Aib-Pro-His-Gly-Ser-NHCbz

weak

P7-E7:

$\mathrm{NH}_{2}$-Val-Gly-C ${ }_{1}$-Aib-Pro-Ser-Gly-Ser-NHCbz

medium-strong

$\mathrm{C} 1=\mathrm{Gua}$ 